\title{
BANGUNAN PENDIDIKAN KARAKTER DI INDONESIA
}

Esti Zaduqisti

Dosen Jurusan Tarbiyah STAIN Pekalongan

\begin{abstract}
Holistic education model using the method of knowing the good, feeling the good, and acting the good. Knowing the good can easily be taught because of cognitive knowledge only. After knowing the good, it must be grown feeling loving the good, that is how to feel and love of virtue into a machine that can make people always want to do something good. Once accustomed to do good things, the good acting then it turns into a habit. The formulation is embodied in a program named: education culture and national character, which is interpreted as an education that develops the cultural values and national character in students. Keywords: Character education and national character.
\end{abstract}

\section{Pendahuluan}

Semakin meningkatnya tantangan hidup di era globalisasi sekarang ini mengharuskan pendidikan dapat memberi bekal kepada pelajar untuk mampu secara mandiri menambah pengetahuan dan wawasannya, melengkapi pengetahuannya, memperbaharui pengetahuannya, dan mengadaptasinya sesuai dengan tuntutan kehidupan. Oleh karena itu, menjadikan pelajar memiliki kemampuan belajar berdasar regulasi diri menjadi tujuan yang harus dicapai oleh sebanyak mungkin pelajar. Kenyataan yang ada menunjukkan bahwa pembelajaran selama ini hanya terfokus pada pengajaran saja, dan belum maksimal diarahkan demi tercapainya perbaikan, kegiatan pengayaan, peningkatan motivasi belajar, serta pengembangan sikap dan kebiasaan belajar yang efektif.

Konteks pendidikan dewasa ini, menurut Handarini (2000), lebih mengutamakan pengembangan intelektual, sehingga menuntut guru menyelesaikan materi pengajaran dan mencapai target kurikulum. Pendidikan di Indonesia hanya mengejar formalitas gelar dan ijazah. Proses pendidikan dilakukan pelajar dengan cara menghafal atas bahan 
yang diberikan oleh guru, bukan berlatih, atau terjun langsung ke hal-hal yang nyata.

Kondisi ini perlu adanya pembenahan dan peran pendidik sangat dibutuhkan, khususnya dalam permasalahan perubahan perilaku. Berdasarkan penelitian di Harvard University Amerika Serikat(Ali Ibrahim Akbar, 2000 dalam Achmad 2010), ternyata kesuksesan seseorang tidak ditentukan semata-mata oleh pengetahuan dan kemampuan teknis (hard skill) saja, tetapi lebih oleh kemampuan mengelola diri dan orang lain (soft skill). Penelitian ini mengungkapkan, kesuksesan hanya ditentukan sekitar 20 persen oleh hard skill dan sisanya 80 persen oleh soft skill.

Tidak salah jika pemerintah sekarang ini meluncurkan program pendidikan karakter. Menteri pendidikan nasional menyatakan bahwa pembangunan karakter adalah bagian penting dalam pembangunan peradaban bangsa. Beberapa karakter yang hendak dibangun berkaitan dengan nilai umum yang diterima masyarakat, antara lain kejujuran, disiplin, dan kebersihan. Program pembangunan karakter bukan hanya dilakukan oleh Kementerian Pendidikan Nasional, tapi juga telah menjadi isu penting di kalangan berbagai ahli pendidikan sehingga pembangunan karakter dapat dilakukan secara serempak di berbagai sektor (Kompas, 19 Juli 2010, h 7). Pendidikan Karakter disinyalir bisa menjadi alternatif solusi upaya peningkatan kualitas pendidikan dan kehidupan manusia.

Bermuara dari program pemerintah yang memasukkan karakter dan budaya bangsa, pendidikan karakter menjadi isu yang hangat dibicarakan dalam konteks pendidikan di Indonesia. Program ini merupakan pelaksanaan dari Undang-Undang Sistem Pendidikan Nasional Pasal 3 yang menyebutkan bahwa pendidikan nasional berfungsi untuk mengembangkan kemampuan dan membentuk karakter serta peradaban bangsa yang bermartabat dalam rangka mencerdaskan kehidupan bangsa. Pendidikan karakter merupakan sistem penanaman nilai-nilai perilaku (karakter) kepada warga sekolah yang meliputi pengetahuan, kesadaran atau kemauan, dan tindakan untuk melaksanakan nilai-nilai, baik terhadap Tuhan Yang Maha Esa, diri sendiri, sesama, lingkungan, maupun kebangsaan sehingga menjadi insan kamil.

Agar program pendidikan karakter tersebut dapat teroptimalisasikan, maka perlu memperhatikan pendidikan karakter yang digagas Foerster yang 
tidak menghapus pentingnya peran metodologi eksperimental maupun relevansi pedagogi naturalis Rousseauian yang merayakan spontanitas dalam pendidikan anak-anak. Yang ingin ditebas oleh arus "idealisme" pendidikan adalah determinisme dan naturalisme yang mendasari paham mereka tentang manusia. Bertentangan dengan determinisme, pendidikan karakter mengasumsikan bahwa manusia mempercayakan dirinya pada dunia nilai. Sebab, nilai merupakan kekuatan penggerak perubahan sejarah. Kemampuan membentuk diri dan mengaktualisasikan nilai-nilai etis merupakan ciri hakiki manusia. Karena itu, mereka mampu menjadi agen perubahan sejarah (Koesoema, 2007).

Pembangunan karakter dan pendidikan karakter menjadi suatu keharusan karena pendidikan tidak hanya menjadikan peserta didik menjadi cerdas, tetapi uga berbudi-pekerti dan memiliki sopan santun sehingga keberadaannya sebagai anggota masyarakat menjadi bermakna baik bagi dirinya maupun orang lain. I Ketut Sumarta dalam bukunya Pendidikan yang Memekarkan Rasa, mengatakan bahwa "Pendidikan nasional kita cenderung hanya menonjolkan pembentukan kecerdasan berpikir dan menepikan penempatan kecerdasan rasa, kecerdasan budi, bahkan kecerdasan batin.

Kutipan di atas menunjukkan bahwa telah terjadi ketidakpuasan atau cenderung terjadinya kegagalan dalam dunia pendidikan dalam rangka membentuk manusia dewasa dan berwatak mandiri. Kegagalan membentuk manusia dewasa dan berwatak mandiri ini bisa diatasi atau diperkecil dengan melakukan program pendidikan karakter (Djudjun, 2009). Inilah angan-angan dan harapan mulia pemerintah dan beberapa pakar pendidikan dalam rangka usahanya untuk membawa bangsa ini kepada kemajuan dan budi pekerti luhur. Persoalannya bagaimana mengimplementasikan pendidikan karakter tersebut dalam pembelajaran di sekolah.

\section{Mengapa Pendidikan Karakter}

Pendidikan karakter telah lama menjadi bagian inti sejarah pendidikan itu sendiri, misalnya dalam cita-cita Paideia Yunani dan Humanitas Romawi. Pendekatan idealis dalam mayarakat modern memuncak dalam ide tentang kesadaran Roh Hegelian. Perkembangan ini pada gilirannya 
mengukuhkan dialektika sebagai sebuah bagian integral dari pendekatan pendidikan karakter (Koesoema, 2007). Pencetus pendidikan karakter yang menekankan dimensi etis-spiritual dalam proses pembentukan pribadi ialah pedagog Jerman FW Foerster (1869-1966). Pendidikan karakter merupakan reaksi atas kejumudan pedagogi natural Rousseauian dan instrumentalisme pedagogis Deweyan. Lebih dari itu, pedagogi puerocentris lewat perayaan atas spontanitas anak-anak (Edouard Claparède, Ovide Decroly, Maria Montessori) yang mewarnai Eropa dan Amerika Serikat awal abad ke-19 kian dianggap tak mencukupi lagi bagi formasi intelektual dan kultural seorang pribadi. Polemik anti-positivis dan anti-naturalis di Eropa awal abad ke-19 merupakan gerakan pembebasan dari determinisme natural menuju dimensi spiritual, bergerak dari formasi personal dengan pendekatan psiko-sosial menuju cita-cita humanisme yang lebih integral. Pendidikan karakter merupakan sebuah usaha untuk menghidupkan kembali pedagogi ideal-spiritual yang sempat hilang

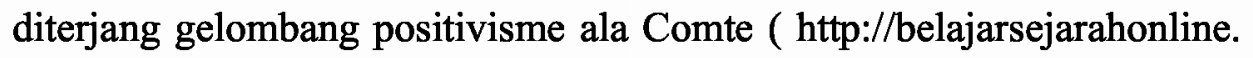
blogspot.com).

Dituliskan oleh Koesoema (2007) di dalam bukunya, bahwa lahirnya pendidikan karakter bisa dikatakan sebagai sebuah usaha untuk menghidupkan kembali pedagogi ideal-spiritual yang sempat hilang diterjang gelombang positivisme yang dipelopori oleh filsuf Prancis Auguste Comte. Foerster menolak gagasan yang meredusir pengalaman manusia pada sekadar bentuk murni hidup alamiah. Dalam sejarah perkembangannya memang manusia tunduk pada hukum-hukum alami, namun kebebasan yang dimiliki manusia memungkinkan dia menghayati kebebasan dan pertumbuhannya mengatasi sekadar tuntutan fisik dan psikis semata. Manusia tidak semata-mata taat pada aturan alamiah. Melainkan kebebasan itu dihayati dalam tata aturan yang sifatnya mengatasi individu, dalam tata aturan nilai-nilai moral.

Dinamika pemahaman pendidikan karakter berproses melalui tiga momen: momen historis, momen reflektif, dan momen praktis. Momen historis, yaitu usaha merefleksikan pengalaman umat manusia yang bergulat dalam menghidupi konsep dan praksis pendidikan khususnya dalam jatuh bangun mengembangkan pendidikan karakter bagi anak didik sesuai dengan konteks zamannya. Momen reflektif, sebuah momen yang 
melalui pemahaman intelektualnya manusia mencoba mendefinisikan pengalamannya, mencoba melihat persoalan metodologis, filosofis, dan prinsipil yang berlaku bagi pendidikan karakter. Momen praktis, yaitu dengan bekal pemahaman teoritis-konseptual, manusia menemukan secara efektif agar proyek pendidikan karakter dapat efektif terlaksana di lapangan (Koesoema, 2007).

Membentuk kepribadian Pendidikan karakter pada hakikatnya ingin membentuk individu menjadi seorang pribadi bermoral yang dapat menghayati kebebasan dan tanggung jawabnya, dalam relasinya dengan orang lain dan dunianya di dalam komunitas pendidikan. Komunitas pendidikan ini bisa memiliki cakupan lokal, nasional, maupun internasional (antar negara). Dengan demikian, pendidikan karakter senantiasa mengarahkan diri pada pembentukan individu bermoral, cakap mengambil keputusan yang tampil dalam perilakunya, sekaligus mampu berperan aktif dalam membangun kehidupan bersama. Singkatnya, bagaimana membentuk individu yang menghargai kearifan nilai-nilai lokal, sekaligus menjadi warganegara dalam masyarakat global.

\section{Konsep Pendidikan Karakter}

Pemahaman konseptual pendidikan karakter sangat diperlukan untuk memahami apa hakekat pendidikan karakter, karena pemahaman konseptual yang baik merupakan setengah jalan dari keberhasilan praksis pendidikan karakter. Tanpa pemahaman konseptual yang jelas, segala usaha yang bagi pengembangan pendidikan karakter akan defisit dalam hal visi sehingga praktis tentang pendidikan karakter bisa salah sasaran dan dan kurang efektif. Oleh karena itu, melalui pemahaman dan kerangka teoritis atas berbagai macam prinsip yang berlaku dalam pendidikan karakter, program-program pendidikan karakter dalam konteks lembaga pendidikan dapat direalisasikan.

Kementerian Pendidikan Nasional merumuskan pendidikan karakter dengan sembilan pilar karakter yang berasal dari nilai-nilai luhur universal, yaitu: pertama, karakter cinta Tuhan dan segenap ciptaan-Nya; kedua, kemandirian dan tanggung-jawab; ketiga, kejujuran/amanah, diplomatis; keempat, hormat dan santun; kelima, dermawan, suka tolong-menolong dan gotong royong/kerjasama; keenam, percaya diri dan pekerja keras; 
ketujuh, kepemimpinan dan keadilan; kedelapan, baik dan rendah hati, dan; kesembilan, karakter toleransi, kedamaian, dan kesatuan. Kesembilan pilar karakter itu, diajarkan secara sistematis dalam model pendidikan holistik menggunakan metode knowing the good, feeling the good, dan acting the good. Knowing the good bisa mudah diajarkan sebab pengetahuan bersifat kognitif saja. Setelah knowing the good harus ditumbuhkan feeling loving the good, yakni bagaimana merasakan dan mencintai kebajikan menjadi mesin yang bisa membuat orang senantiasa mau berbuat sesuatu kebaikan. Setelah terbiasa melakukan kebajikan, maka acting the good itu berubah menjadi kebiasaan.

Rumusan tersebut diejawantahkan dalam programnya yang bernama: pendidikan budaya dan karakter bangsa, yang dimaknai sebagai pendidikan yang mengembangkan nilai-nilai budaya dan karakter bangsa pada diri peserta didik sehingga mereka memiliki nilai dan karakter sebagai karakter dirinya, menerapkan nilai-nilai tersebut dalam kehidupan dirinya, sebagai anggota masyarakat, dan warga negara yang religius, nasionalis, produktif, dan kreatif. Adapun tujuan pendidikan budaya dan karakter bangsa yang dirumuskan oleh Kemendiknas adalah:

- mengembangkan potensi kalbu/nurani/afektif peserta didik sebagai manusia dan warganegara yang memiliki nilai-nilai budaya dan karakter bangsa,

- mengembangkan kebiasaan dan perilaku peserta didik yang terpuji dan sejalan dengan nilai-nilai universal dan tradisi budaya bangsa yang religius,

- menanamkan jiwa kepemimpinan dan tanggung jawab peserta didik sebagai generasi penerus bangsa,

- mengembangkan kemampuan peserta didik menjadi manusia yang mandiri, kreatif, berwawasan kebangsaan, dan

- mengembangkan lingkungan kehidupan sekolah sebagai lingkungan belajar yang aman, jujur, penuh kreativitas dan persahabatan, serta dengan rasa kebangsaan yang tinggi dan penuh kekuatan (dignity).

Selain tujuan, pendidikan budaya dan karakter bangsa juga mempunyai nilai-nilai yang dikembangkan dan diidentifikasi dari sumbersumber berikut ini: 
- Agama: masyarakat Indonesia adalah masyarakat beragama. Oleh karena itu, kehidupan individu, masyarakat, dan bangsa selalu didasari pada ajaran agama dan kepercayaannya. Secara politis, kehidupan kenegaraan pun didasari pada nilai-nilai yang berasal dari agama. Atas dasar pertimbangan itu, maka nilai-nilai pendidikan budaya dan karakter bangsa harus didasarkan pada nilai-nilai dan kaidah yang berasal dari agama.

- Pancasila: negara kesatuan Republik Indonesia ditegakkan atas prinsipprinsip kehidupan kebangsaan dan kenegaraan yang disebut Pancasila. Artinya, nilai-nilai yang terkandung dalam Pancasila menjadi nilai-nilai yang mengatur kehidupan politik, hukum, ekonomi, kemasyarakatan, budaya, dan seni. Pendidikan budaya dan karakter bangsa bertujuan mempersiapkan peserta didik menjadi warga negara yang lebih baik, yaitu warga negara yang memiliki kemampuan, kemauan, dan menerapkan nilainilai Pancasila dalam kehidupannya sebagai warga negara.

- Budaya: sebagai suatu kebenaran bahwa tidak ada manusia yang hidup bermasyarakat yang tidak didasari oleh nilai-nilai budaya yang diakui masyarakat itu. Nilai-nilai budaya itu dijadikan dasar dalam pemberian makna terhadap suatu konsep dan arti dalam komunikasi antaranggota masyarakat itu. Posisi budaya yang demikian penting dalam kehidupan masyarakat mengharuskan budaya menjadi sumber nilai dalam pendidikan budaya dan karakter bangsa.

- Tujuan Pendidikan Nasional: sebagai rumusan kualitas yang harus dimiliki setiap warga negara Indonesia, dikembangkan oleh berbagai satuan pendidikan di berbagai jenjang dan jalur. Tujuan pendidikan nasional memuat berbagai nilai kemanusiaan yang harus dimiliki warga negara Indonesia. Oleh karena itu, tujuan pendidikan nasional adalah sumber yang paling operasional dalam pengembangan pendidikan budaya dan karakter bangsa.

Berdasarkan keempat sumber nilai itu, teridentifikasi sejumlah nilai untuk pendidikan budaya dan karakter bangsa sebagai berikut ini: 


\begin{tabular}{|c|c|}
\hline NILAI & DESKRIPSI \\
\hline 1. Religius & $\begin{array}{l}\text { Sikap dan perilakuyang patuh dalam melaksanakan } \\
\text { ajaran agama yang dianutnya, toleran terhadap } \\
\text { pelaksanaan ibadah agama lain, dan hidup rukun } \\
\text { dengan pemeluk agama lain }\end{array}$ \\
\hline 2. Jujur & $\begin{array}{l}\text { Perilaku yang didasarkan pada upaya menjadikan } \\
\text { dirinya sebagai orang yang selalu dapat dipercaya } \\
\text { dalam perkataan, tindakan, dan pekerjaan. }\end{array}$ \\
\hline 3. Toleransi & $\begin{array}{l}\text { Sikap dan tindakan yang menghargai perbedaan } \\
\text { agama, suku, etnis, pendapat, sikap, dan tindakan } \\
\text { orang lain yang berbeda dari dirinya }\end{array}$ \\
\hline 4. Disiplin & $\begin{array}{l}\text { Tindakan yang menunjukkan perilaku tertib dan } \\
\text { patuh pada berbagai ketentuan dan peraturan }\end{array}$ \\
\hline 5. Kerja Keras & $\begin{array}{l}\text { Perilaku yang menunjukkan upaya sungguh- } \\
\text { sungguh dalam mengatasi berbagai hambatan } \\
\text { belajar dan tugas, serta menyelesaikan tugas } \\
\text { dengan sebaik-baiknya }\end{array}$ \\
\hline 6. Kreatif & $\begin{array}{l}\text { Berpikir dan melakukan sesuatu untuk menghasil- } \\
\text { kan cara atau hasil baru dari sesuatu yang telah } \\
\text { dimiliki. }\end{array}$ \\
\hline 7. Mandiri & $\begin{array}{l}\text { Sikap dan perilaku yang tidak mudah tergantung } \\
\text { pada orang lain dalam menyelesaikan tugas-tugas. }\end{array}$ \\
\hline 8. Demokratis & $\begin{array}{l}\text { Cara berfikir, bersikap, dan bertindak yang menilai } \\
\text { sama hak dan kewajiban dirinya dan orang lain. }\end{array}$ \\
\hline $\begin{array}{l}\text { 9. Rasa Ingin } \\
\text { Tahu }\end{array}$ & $\begin{array}{l}\text { Sikap dan tindakan yang selalu berupaya untuk } \\
\text { mengetahui lebih mendalam dan meluas dari } \\
\text { sesuatu yang dipelajarinya, dilihat, dan didengar }\end{array}$ \\
\hline $\begin{array}{l}\text { 10. Semangat } \\
\text { Kebangsaan }\end{array}$ & $\begin{array}{l}\text { Cara berpikir, bertindak, dan berwawasan yang } \\
\text { menempatkan kepentingan bangsa dan negara di } \\
\text { atas kepentingan diri dan kelompoknya }\end{array}$ \\
\hline
\end{tabular}




\begin{tabular}{|c|c|}
\hline $\begin{array}{l}\text { 11. Cinta Tanah } \\
\text { Air }\end{array}$ & $\begin{array}{l}\text { Cara berfikir, bersikap, dan berbuat yang } \\
\text { menunjukkan kesetiaan, kepedulian, dan peng- } \\
\text { hargaan yang tinggi terhadap bahasa, lingkungan } \\
\text { fisik, sosial, budaya, ekonomi, dan politik bangsa }\end{array}$ \\
\hline $\begin{array}{l}\text { 12. Menghargai } \\
\text { Prestasi }\end{array}$ & $\begin{array}{l}\text { Sikap dan tindakan yang mendorong dirinya } \\
\text { untuk menghasilkan sesuatu yang berguna bagi } \\
\text { masyarakat, dan mengakui, serta menghormati } \\
\text { keberhasilan orang lain. }\end{array}$ \\
\hline $\begin{array}{l}\text { 13. Bersahabat/ } \\
\text { Komunikatif }\end{array}$ & $\begin{array}{l}\text { Tindakan yang memperlihatkan rasa senang } \\
\text { berbicara, bergaul, dan bekerja sama dengan orang } \\
\text { lain. }\end{array}$ \\
\hline 14. Cinta Damai & $\begin{array}{l}\text { Sikap, perkataan, dan tindakan yang menyebabkan } \\
\text { orang lain merasa senang dan aman atas kehadiran } \\
\text { dirinya }\end{array}$ \\
\hline $\begin{array}{l}\text { 15. Gemar } \\
\text { Membaca }\end{array}$ & $\begin{array}{l}\text { Kebiasaan menyediakan waktu untuk membaca } \\
\text { berbagai bacaan yang memberikan kebajikan bagi } \\
\text { dirinya }\end{array}$ \\
\hline $\begin{array}{l}\text { 16. Peduli } \\
\text { Lingkungan }\end{array}$ & $\begin{array}{l}\text { Sikap dan tindakan yang selalu berupaya mencegah } \\
\text { kerusakan pada lingkungan alam di sekitarnya, dan } \\
\text { mengembangkan upaya-upaya untuk memperbaiki } \\
\text { kerusakan alam yang sudah terjadi }\end{array}$ \\
\hline 17. Peduli Sosial & $\begin{array}{l}\text { Sikap dan tindakan yang selalu ingin memberi } \\
\text { bantuan pada orang lain dan masyarakat yang } \\
\text { membutuhkan }\end{array}$ \\
\hline $\begin{array}{l}\text { 18. Tanggung- } \\
\text { jawab }\end{array}$ & $\begin{array}{l}\text { Sikap dan perilaku seseorang untuk melaksanakan } \\
\text { tugas dan kewajibannya, yang seharusnya dia } \\
\text { lakukan, terhadap diri sendiri, masyarakat, } \\
\text { lingkungan (alam, sosial dan budaya), negara dan } \\
\text { Tuhan_Yang_Maha.Esa }\end{array}$ \\
\hline
\end{tabular}




\section{Prinsip-Prinsip Pengembangan Pendidikan Budaya dan Karakter}

Ada empat prinsip dasar pengembangan pendidikan budaya dan karakter bangsa di Indonesia yang dirumuskan Kemendiknas,antara lain:

- Berkelanjutan

Mengandung makna bahwa proses pengembangan nilai-nilai budaya dan karakter bangsa merupakan sebuah proses panjang, dimulai dari awal peserta didik masuk sampai selesai dari suatu satuan pendidikan. Sejatinya, proses tersebut dimulai dari kelas 1 SD atau tahun pertama dan berlangsung paling tidak sampai kelas 9 atau kelas akhir SMP. Pendidikan budaya dan karakter bangsa di SMA adalah kelanjutan dari proses yang telah terjadi selama 9 tahun.

- Melalui semua mata pelajaran, pengembangan diri, dan budaya sekolah Mensyaratkan bahwa proses pengembangan nilai-nilai budaya dan karakter bangsa dilakukan melalui setiap mata pelajaran, dan dalam setiap kegiatan kurikuler dan ekstrakurikuler. Pengembangan nilai budaya dan karakter bangsa melalui berbagai mata pelajaran yantelah ditetapkan dalam Standar Isi (SI) digambarkan sebagai berikut:

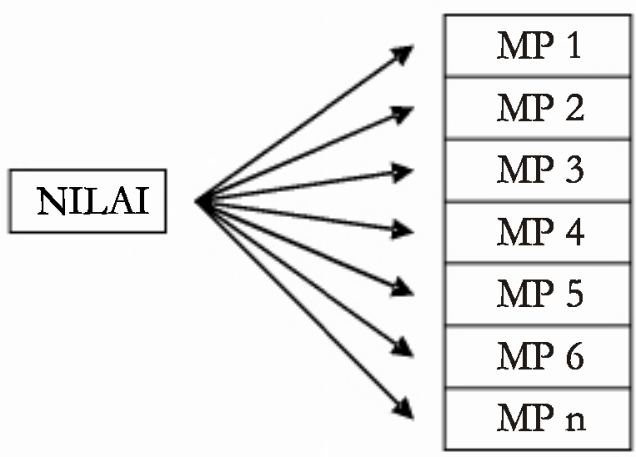

Seperti dikatakan oleh Sudrajat (2010) pendidikan karakter dapat diintegrasikan dalam pembelajaran pada setiap mata pelajaran. Materi pembelajaran yang berkaitan dengan norma atau nilai-nilai pada setiap mata pelajaran perlu dikembangkan, dieksplisitkan, dikaitkan dengan konteks kehidupan sehari-hari. Dengan demikian, pembelajaran nilainilai karakter tidak hanya pada tataran kognitif, tetapi menyentuh pada internalisasi, dan pengamalan nyata dalam kehidupan peserta didik seharihari di masyarakat. 
- Nilai tidak diajarkan tapi dikembangkan

Mengandung makna bahwa materi nilai budaya dan karakter bangsa bukanlah bahan ajar biasa; artinya, nilai-nilai itu tidak dijadikan pokok bahasan yang dikemukakan seperti halnya ketika mengajarkan suatu konsep, teori, prosedur, ataupun fakta seperti dalam mata pelajaran agama, bahasa Indonesia, PKn, IPA, IPS, matematika, pendidikan jasmani dan kesehatan, seni, dan ketrampilan.

- Proses pendidikan dilakukan peserta didik secara aktif dan menyenangkan

Proses pendidikan nilai budaya dan karakter bangsa dilakukan oleh peserta didik bukan oleh guru. Guru menerapkan prinsip "tut wuri handayani" dalam setiap perilaku yang ditunjukkan peserta didik. Prinsip ini juga menyatakan bahwa proses pendidikan dilakukan dalam suasana belajar yang menimbulkan rasa senang dan tidak indoktrinatif. Diawali dengan perkenalan terhadap pengertian nilai yang dikembangkan maka guru menuntun peserta didik agar aktif. Hal ini dilakukan tanpa guru mengatakan kepada peserta didik bahwa mereka harus aktif, tapi guru merencanakan kegiatan belajar yang menyebabkan peserta didik aktif merumuskan pertanyaan, mencari sumber informasi, dan mengumpulkan informasi dari sumber, mengolah informasi yang sudah dimiliki, merekonstruksi data, fakta, atau nilai, menyajikan hasil rekonstruksi atau proses pengembangan nilai, menumbuhkan nilai-nilai budaya dan karakter pada diri mereka melalui berbagai kegiatan belajar yang terjadi di kelas, sekolah, dan tugas-tugas di luar sekolah.

Pemerintah telah merumuskan sembilan pilar pendidikan karakter (CEP,2007), yaitu:

- Promotes core ethical values and supportive performance values as the foundation of good character. Pendidikan karakter mempromosikan nilai-nilai etika yang inti sebagai basis karakter yang baik.

- Defines "character" comprehensively to include thinking, feeling, and behavior. Karakter harus didefinisikan secara komprehensif yang mencakup pikiran perasaan dan tindakan.

- Uses a comprehensive, intentional, and proactive approach to character 
development. Pendidikan karakter yang efektif mempersyaratkan pendekatan yang terencana, proaktif, dan komprehensif yang mempromosikan nilai-nilai hakiki pada semua tingkat pendidikan.

- Creates a caring school community. Sekolah harus merupakan masyarakat yang peduli.

- Provides students with opportunities for moral action. Untuk mengembangkan karakter, siswa perlu memperoleh kesempatan untuk bertindak secara moral.

- Includes a meaningful and challenging academic curriculum that respects all learners, develops their character, and helps them to succeed. Pendidikan karakter yang efektif mencakup kurikulum yang challenging dan bermakna yang menghargai semua pembelajar dan menolong mereka untuk berhasil.

- Strives to foster students' selfmotivation. Pendidikan karakter harus diarahkan untuk mengembangkan motivasi intrinsik siswa.

- Engages the school staff as a learning and moral community that shares responsibility for character education and attempts to adhere to the same core values that guide the education of students. Staf sekolah harus menjadi masyarakat belajar moral dan berbagi tanggung jawab dalam pendidikan karakter serta berusaha untuk menunjukkan nilainilai yang dapat dijadikan model oleh para siswa.

- Fosters shared moral leadership and longrange support of the character education initiative. Pendidikan karakter mempersyaratkan kepemimpinan yang bermoral

- Engages families and community members as partners in the characterbuilding effort. Sekolah harus melibatkan masyarakat sebagai partner dalam usaha membangun karakter.

- Assesses the character of the school, the school staff's functioning as character educators, and the extent to which students manifest good character. Evaluasi dalam pendidikan karakter harus mencakup pengukuran karakter sekolah, apakah staf sekolah berfungsi sebagai pendidik karakter, yang berdampak pada karakter para siswa.

Menurut Foerster (dalam Koesoema, 2007) ada empat ciri dasar dalam pendidikan karakter. Pertama, keteraturan interior di mana setiap tindakan diukur berdasar hierarki nilai. Nilai menjadi pedoman normatif 
setiap tindakan. Kedua, koherensi yang memberi keberanian, membuat seseorang teguh pada prinsip, tidak mudah terombang-ambing pada situasi baru atau takut risiko. Koherensi merupakan dasar yang membangun rasa percaya satu sama lain. Tidak adanya koherensi meruntuhkan kredibilitas seseorang. Ketiga, otonomi. Di situ seseorang menginternalisasikan aturan dari luar sampai menjadi nilai-nilai bagi pribadi. Ini dapat dilihat lewat penilaian atas keputusan pribadi tanpa terpengaruh atau desakan pihak lain. Keempat, keteguhan dan kesetiaan. Keteguhan merupakan daya tahan seseorang guna mengingini apa yang dipandang baik. Dan kesetiaan merupakan dasar bagi penghormatan atas komitmen yang dipilih. Kematangan keempat karakter ini, lanjut Foerster, memungkinkan manusia melewati tahap individualitas menuju personalitas. "Orang-orang modern sering mencampuradukkan antara individualitas dan personalitas, antara aku alami dan aku rohani, antara independensi eksterior dan interior." Karakter inilah yang menentukan forma seorang pribadi dalam segala tindakannya.

Sudrajat (2010) mengatakan bahwa pendidikan karakter di sekolah selama ini baru menyentuh pada tingkatan pengenalan norma atau nilainilai, dan belum pada tingkatan internalisasi dan tindakan nyata dalam kehidupan sehari-hari. Salah satu alternatif untuk mengatasi permasalahan tersebut adalah melalui pendidikan karakter terpadu, yaitu memadukan dan mengoptimalkan kegiatan pendidikan informal lingkungan keluarga dengan pendidikan formal di sekolah. Dalam hal ini, waktu belajar peserta didik di sekolah perlu dioptimalkan agar peningkatan mutu hasil belajar dapat dicapai, terutama dalam pembentukan karakter peserta didik.

\section{Praksis Pendidikan Karakter di Lapangan}

Mencermati praktek yang ada di lapangan, jika yang dijadikan tolak ukur adalah seperti yang dijabarkan dalam konsep, serta berbagai pendapat para pakar pendidikan, secara umum program pendidikan belum begitu nampak di lapangan. Tujuan yang diharapkan, yaitu mengembangkan potensi kalbu/nurani/afektif peserta didik sebagai manusia dan warganegara yang memiliki nilai-nilai budaya dan karakter bangsa; mengembangkan kebiasaan dan perilaku peserta didik yang terpuji dan sejalan dengan nilainilai universal dan tradisi budaya bangsa yang religius; menanamkan jiwa 
kepemimpinan dan tanggung jawab peserta didik sebagai generasi penerus bangsa; mengembangkan kemampuan peserta didik menjadi manusia yang mandiri, kreatif, berwawasan kebangsaan; dan mengembangkan lingkungan kehidupan sekolah sebagai lingkungan belajar yang aman, jujur, penuh kreativitas dan persahabatan, serta rasa kebangsaan yang tinggi dan penuh kekuatan (dignity), semunya belum secara optimal.

Pendidikan karakter, hanya semacam menara gading, yang konsep, filosofi, dan rancangannya sangat mulia dan indah, namun pelaksanaannya masih sangat susah dijalankan. Belum terlihat jelas karakter manusia Indonesia yang seperti ada dalam sembilan pilar pendidikan karakter. Religius? Masih banyak yanng melanggar aturan agama dan tidak komitmen dengan yang diyakini dalam agamanya. Jujur? Korupsi yang menjadi fenomena yang buruk, belum bisa diberantas, Toleransi? Masih banyak konflik yang terjadi karena tidak ada toleransi dan saling menghormati. Disiplin dan kerja keras? Bahkan karena dua hal tersebut indonesia selalu tertinggal dengan negara lain. Kreatif, mandiri dan seterusnya, semakin memperlihatkan seakan pendidikan karakter hanya sebagai pertama yang tersimpan rapi, dan tak bisa disentuh dan dipakai.

\section{Penutup}

Sebagai kesimpulan dari pembahasan adalah bahwa pendidikan karakter merupakan sebuah konsep yang ideal yang implementasinya diperlukan komitmen, dan dukungan dari semua pihak, mulai dari individu, keluarga, staf dan pegawai administrasi, guru, kepala sekolah dan bahkan pemerintah. Dan yang paling penting adalah komitmen diri untuk mewujudkan terciptanya karakter dan budi pekerti luhur sesuai dengan budaya bangsa Indonesia.

\section{Daftar Pustaka}

Budimansyah, D. 2011 Pendidikan Umum dalam Perspektif Pendidikan Karakter Bangsa.http://berita.upi.edu//02/18. diakses tanggal 12 februari 2011.

Character Education Partnership. 2007. CEP's Eleven Principles of 
Effective Character Education. www. Character.org. diakses 30 maret 2011.

Djudjun, 2009, Program Pendidikan Karakter di Lingkungan BPK PENABUR Jakarta, Tabloid Penabur, Jakarta Edisi Maret - April 2009 No. 25 THN. VI.

Kementrian Pendidikan Nasional (2010). Pengembangan pendidikan budaya dan karakter bangsa. Bahan Pelatihan Penguatn Metodologi Pembelajaran berdasarkan Nilai-nilai Budaya untu membentuk daya saing dan karakter bangsa. Badan Penelitian dan Pengembangan Pusat Kurikulum.

Koesoema D.A. 2007. Pendidikan Karakter; Strategi Mendidik Anak di Zaman Modern Jakarta: PT. Grasindo Pertama.

Suyanto. tt. Urgensi Pendidikan Karakter. Ditjen Mendikdasmen Kementerian Pendidikan Nasional 